\title{
QUEEN'S
UNIVERSITY
BELFAST
}

\section{Education for Citizenship Education and Social Justice in Northern Ireland}

Gallagher, A., \& Duffy, G. (2016). Education for Citizenship Education and Social Justice in Northern Ireland. In A. Peterson, R. Hattam, M. Zembylas, \& J. Arthur (Eds.), The Palgrave International Handbook of Education for Citizenship and Social Justice (pp. 523-544). Palgrave Macmillan Ltd..

http://www.palgrave.com/gp/book/9781137515063

Published in:

The Palgrave International Handbook of Education for Citizenship and Social Justice

Document Version:

Peer reviewed version

Queen's University Belfast - Research Portal:

Link to publication record in Queen's University Belfast Research Portal

\section{Publisher rights}

Gallagher \& Duffy, 'Education for Citizenship Education and Social Justice in Northern Ireland' in 'The Palgrave International Handbook of Education for Citizenship and Social Justice', 2016, Copyright 2016, 978-1-137-51507-0 reproduced with permission of Palgrave Macmillan. The following statement must also be displayed: This extract is taken from the author's original manuscript and has not been edited. The definitive, published, version of record is available here: http://www.palgrave.com/gp/book/9781137515063

\section{General rights}

Copyright for the publications made accessible via the Queen's University Belfast Research Portal is retained by the author(s) and / or other copyright owners and it is a condition of accessing these publications that users recognise and abide by the legal requirements associated with these rights.

Take down policy

The Research Portal is Queen's institutional repository that provides access to Queen's research output. Every effort has been made to ensure that content in the Research Portal does not infringe any person's rights, or applicable UK laws. If you discover content in the Research Portal that you believe breaches copyright or violates any law, please contact openaccess@qub.ac.uk. 
Citizenship education in Northern Ireland

Tony Gallagher and Gavin Duffy

School of Social Sciences, Education and Social Work

Queen's University Belfast

January 2016

Introduction

Citizenship education is often focused on the symbols and rituals that, in a Durkheimian manner, provide bonds of connection within a national community (Durkheim and Lukes, 2013). How might this operate in a divided society, one in which the fault-lines of politics, nationality and religion overdetermine one another? This is the challenge facing Northern Ireland, an area which carried an historical burden of conflict and division, including a recent period when political violence scarred the landscape for over a quarter century. Almost the same time period has now elapsed since the paramilitary ceasefires in 1994, but old divisions die hard, and although new shared political institutions have emerged, and have successfully navigated two electoral cycles, politics still has a strongly confessional/national character. When we add to this mix the fact that Northern Ireland has always operated with denominationally separate schools, then the challenge of formulating and implementing a citizenship education programme becomes even more marked. This chapter examines this experience, beginning with an outline of the historical and educational background to highlight some of the challenges that were being faced. The chapter then examines the genesis and development of the citizenship education programme, before providing an outline of its structure and form. The final part of the chapter reviews evidence on the impact of citizenship education in Northern Ireland and a number of critical perspectives on this and related educational measures.

\section{$\underline{\text { Historical context and background }}$}

Northern Ireland is a place where national, political and religious identity are closely linked and always contentious. Britain has exerted control over some part of Ireland since the 12th century, but it was not consolidated until the 17th century at which point mainly Scottish settlers were 'planted' in the north east area of the island. Almost a century later the Glorious Revolution in England confirmed the Protestant monarchy and Ireland provided the location for a series of battles, many of which continue to be commemorated in Northern Ireland today by the Protestant Orange Order. At the end of the 18th century, and inspired by the American and French Revolutions, the United Irishmen launched a rebellion to separate Ireland from Britain: the rebellion not only failed, but provoked the 1801 Act of Union which dissolved the Irish parliament. Perhaps more important, the rebellion took distinct forms across the island: Presbyterian radicals led the rebellion in the northern part of the island, but in large parts of the south large armies of Catholic peasants, led by priests, massacred Protestants. The arrest, execution or expulsion into exile of the radical leaders was one of the reasons why the politics of Ireland took on an increasingly denominational character from this point on. As the 19th century progressed and the franchise was extended the link between denomination and politics strengthened as the Catholic majority on the island increasingly asserted itself and sought the restoration of an Irish parliament and home rule. 
The Protestant minority on the island was largely concentrated in the north east, the only area of the island to benefit significantly from the industrial revolution. While Irish nationalists came to represent the Catholic majority, the Protestant community consolidated around support for the Union between Britain and Ireland and support unionist politicians: in their eyes Protestantism and Britishness were intertwined, but the importance of the global economic market provided by the British Empire was another important, and very practical, reason why Northern Protestants saw little to attract them in an independent Ireland, where economic considerations would inevitably be dominated by rural interests.

The increasingly diverse paths being taken by the two main communities in Ireland came to a head after the passage of the 1912 Home Rule Bill by the Westminster parliament. Implementation of the Bill was delayed as a consequence of the First World War and all other considerations were swept aside by the Dublin Rising in 1916. This attempt to seize power failed, but it sparked off a war of independence which eventually led to the establishment of two parliaments, in Dublin and Belfast, each of which was given the authority to determine the future of each part of the island (Daly, 2010). The Dublin parliament opted for independence, and Irish Free State and later the Irish Republic. The Belfast parliament opted to stay in the United Kingdom and, from 1922 onwards, operated as an autonomous region within the UK. The Irish Free State had an overwhelming Catholic majority, but Northern Ireland was left with a Protestant majority and a significant Catholic minority. This fact came to dominate politics in Northern Ireland: the Catholic minority identified as Irish and continually claimed to suffer discrimination from the Protestant and unionist dominated parliament; the Protestant majority worked to consolidate its hold on power and seemed always to see Catholics as an 'enemy within' seeking to dismantle the jurisdiction and demolish the border between north and south.

At various points the unionist-nationalist tension broke out in violence, but never so seriously as in the late 1960s. A Northern Ireland Civil Rights campaign in the 1960s mimicked the US campaign and sought to challenge discrimination in employment and public services, but it faced an uncompromising state (Rose, 1976). Civil disorder and riots broke out, followed closely by the involvement of Irish Republican paramilitaries, the decision by the British government to send in the Army to shore up the police and the establishment of Protestant paramilitary groups. In a short few years the national/political/religious struggle had turned violent; progress, or the lack of it, was measured in the body-count; and 'normal' politics was abandoned. The Northern Ireland parliament was suspended in 1972. In 1973 an Assembly was elected and agreed power-sharing arrangements between unionist and nationalist political parties, but it faced opposition from militant unionists and collapsed in 1974. In 1975 a Constitutional Convention was elected and tasked with the idea of bringing forward consensus proposals on new political arrangements. It failed. In 1982 another Assembly was elected, but nationalist representatives declined to participate and it did not last. In 1996 a Northern Ireland Forum was elected as part of the process leading to the Good Friday Agreement (GFA) in 1998. In 1998 a new Assembly was elected on the basis of the GFA, but failed to establish new shared political arrangements until 2000. A series of suspensions followed until 2002 when the Assembly went into longer-term suspension, despite another election in 2003. Further political talks agreed a way forward, and another Assembly election, in 2007. This time the Assembly continued to function and operated successfully through another election in 2011. A further crisis in 
2014 was averted by talks and agreement in 2015 which allowed the next Assembly election to proceed.

Political representation in the NI Assembly is dominated by political parties with a largely confessional base: the Ulster Unionist Party (UUP) and Democratic Unionist Party (DUP) draw most of their support from Protestants; the Social Democratic and Labour Party (SDLP) and Sinn Fein (SF) draw most of their support from Catholics; only the Alliance Party (AP) seeks and draws support from across the communities, and of these 'Big Five' parties, it is the one with the lowest level of support. There is also a miscellany of independents and smaller parties represented in the Assembly, but it is the 'Big Five' which hold most seats and, under the GFA, have the right to ministerial seats in the NI Executive. Traditionally the DUP and SF have always been the more militant parties in unionism and nationalism respectively. In 1998 the UUP and SDLP were the two largest parties and led the Executive, but by 2007 the DUP and SF had become the largest parties, a pattern that was strengthened in the 2011 and 2016 NI Assembly elections.

One further area of context is necessary: a National School system was established in Ireland in the 1830s, with the avowed aim of teaching children of all denominations together. This lofty ambition was never realised as the Churches consolidated their control over schooling (Akenson, 1970). The Catholic Church continued to dominate schooling in the Irish Free State and Irish Republic, but in Northern Ireland the first Minister of Education in 1922 tried to shift the orientation of schooling away from the Churches and towards local authorities, on the English model. This ambition also largely failed: the Catholic Church refused to give over control of its schools to the local authorities, while the Protestant Churches only did so when they had won concessions from the government that largely restored their influence over the schools (Akenson, 1973). It was not until 1981 that the first religiously integrated school was opened and the integrated sector now accounts for only 7 per cent of all pupils. The GFA included a clause urging support for further developments in integrated education, but it also included support for the even smaller sector of Irish medium schools, where all teaching is delivered through the Irish language.

In such a context, where identity is so heavily infused by different religious and national elements, and appears to be fed by a mixture of historical myth, symbolism and anger, how is it possible to teach citizenship in a way which rises above partisan interests and discourses?

\section{Education, the conflict in Northern Ireland and the development of citizenship education}

Right from the start of the political violence in the late 1960s people looked to the schools in Northern Ireland to do something. On the one hand some asked whether the system of separate Protestant and Catholic schools simply served to reinforce difference and division (Heskins, 1980), but on the other hand many educators attempted a variety of interventions to try and provide young people with some concepts, language or practice to navigate their way through an increasingly distressing reality. Some tried to break down the institutional barriers between young people through contact initiatives or, as noted above, the establishment of new religiously integrated schools (Gallagher, 2004). At another time there was a more marked focus on the role of schools on labour market opportunity and equality, leading to equal funding for Catholic schools (Gallagher et al., 1994), while currently the main structural focus is on shared education and the establishment of 
collaborative links between Protestant and Catholic schools (Duffy and Gallagher, 2014). Back in the early 1970s the initial intervention focused on the curriculum and the teaching of history and religion. By the 1980s new programmes to promote mutual understanding and greater tolerance of cultural differences had emerged (Richardson and Gallagher 2010). These had followed education reforms in England and Wales which established a statutory curriculum, including a citizenship theme, a notable absence in the Northern Ireland curriculum (Whitty et al, 1994).

By the time of the GFA and the peace process the statutory curriculum in Northern Ireland had come to be seen as over-loaded and in need of serious review. In line also with the rapidly changing political context, and the recognition that previous education interventions to address division and reconciliation had had limited success (Gallagher, 2004), there was growing interest in the development of a citizenship programme for schools, allied with a recognition that this might involve some radical re-thinking of how schools operated (Lister, 1998, Horgan and Rodgers, 2000). The GFA had included a commitment to promoting a culture of tolerance through education and, in order to advance this agenda, the Department of Education established two working groups. The first of these recommended more effective guidance for schools wishing to adopt integrated status and encouraged local authorities to carry out community audits to better gauge support for integrated education. In addition, it recommended support for all schools wishing to meet the challenges of pluralism in society and recognised that this was a mission to which all schools could and should contribute (Department of Education, 1998). The second working group focused on measures aimed at promoting better community relations and identified limitations with the then current approaches within the curriculum (Department of Education, 1999).

The idea of teaching citizenship in Northern Ireland linked into the theme of the second working party report. Smith (2003) suggested that the main challenge lay in the lack of consensus on national identity and suggested that a concept of citizenship based on rights and responsibilities might provide a more productive basis for development. The Social, Civic and Political Education project was established by the Citizenship Foundation, the Council for the Curriculum, Examinations and Assessment (CCEA) and the University of Ulster in order to pilot a citizenship curriculum (see also Arlow, 2001, 2004, Watling and Arlow, 2002)

The pilot work suggested that an enquiry-based approach was more appropriate than one which was primarily knowledge-based and transmissional, and it identified four themes each of which focused on the processes of citizenship: (1) diversity and inclusion, (2) equality and justice (3) human rights and social responsibilities, and (4) democracy and active participation. The themes would be explored through case studies and resource materials, focusing on different levels from the local, national, European to the global. NGOs also produced educational materials and schools were encouraged to work with them.

Smith (2003) identified a number of possible problems: the NI curriculum was largely content based and subject dominated, so the proposed approach ran counter to the prevailing norm in schools. There was also a pedagogical challenge as the statutory curriculum had changed the nature of teaching towards a focus on delivery, rather than the development of new methods for addressing difficult or controversial issues, although Watling and Arlow (2002) felt this could be addressed if the curriculum was 'explored collaboratively rather than taught didactically' (Watling and Arlow, 2002: 
170). In a nod to the ongoing political process, Smith (2003) also suggested there was a wider societal challenge to be faced, depending on whether Northern Ireland was going to work towards a shared future, or opt for one in which difference was consolidated and managed: each of these implied differences in people's sense of belonging and hence would influence concepts and understanding of citizenship.

The evaluation of the pilot found that teachers and pupils were strongly motivated and positive about the project. Teachers valued being given a role in the development of the project and the way it challenged some of the more traditional and narrow forms of classroom practice, and they welcomed the support from the project team, and the role of NGOs. Arising from this Watling and Arlow (2002) made four recommendations: (1) since the curriculum was already crowded, this work needed unambiguous support from the leadership of schools in order to work; (2) while flexibility was valued, the teachers wanted clarity on materials, resources and teaching priorities, (3) any training provided must be of high quality, (4) and an externally validated award should be available. Wylie (2004) argued that an effective citizenship programme would always be constrained by the system of separate denominational schools, but suggested that proposals for collaborative collegiates arising from the review of the selective system of secondary education in Northern Ireland (Burns, 2001; Gallagher, 2005) might provide a supportive context, a possibility that was probably strengthened by the development of shared education (Ben-Porath, 2011; Gallagher, 2011; Duffy and Gallagher, 2014). Arlow (2001) was very positive about the potential for citizenship education, especially after the limitations of previous curriculum approaches, and described the new programme as a potentially 'defining moment in the education system's response to the conflict' ( $p$ 43). However, probably as a consequence of the suspension of the NI Assembly in 2002 and limited political progress, Arlow (2004) was a little more circumspect. The debate over academic selection had become a unionist/nationalist debate, with the former opposing a move away from selection and the latter favouring it, and this dispute had begun to sour debates on education policy more generally. The revised NI curriculum had originally been targeted for implementation in 2001, but by the time Arlow (2004) had written his paper the deadline had shifted to 2005. In fact, it was not until 2007 that legislation for the new curriculum was passed, suggesting that Gallagher's (2005) words of caution about modest expectations had been prescient.

Before then funding for a major development programme had been put in place by the Department of Education, with resources made available so that all schools had teachers trained to deliver the new citizenship programme. Five full-time officers were appointed to the local authorities to supervise the training and support the teachers, and high quality materials were produced.

\section{The citizenship education programme}

In primary school pupils (aged 4 to 11 years) follow the 'Living. Learning. Together' programme. One of the strands of this programmes is 'Mutual Understanding in the Local and Wider Community' which covers a range of issues over the seven years of primary education including, for example, 'belonging and cooperating', 'getting along with others' and 'valuing self and others.

At post-primary school pupils (aged 11 to 15 years) follow the Learning for Life and Work Programme which contains four themes: 'Education for Employability', Home Economics', Personal 
Development' and 'Local and Global Citizenship' (LGC). Pupils (aged 15 to 16 years) can opt to take a recognised qualification (GCSE) in Learning for Life and Work, where pupils follow the themes identified above except for Home Economics. LGC can be provided as a discrete subject (which is strongly recommended), in a cross-curricular manner, on a whole-school basis, or through extracurricular activities and community links. In the curriculum guidance material the four main themes are described as follows (all sourced from CCEA Key Stage 4 guidance material):

Diversity and inclusion:

- Investigation of the concepts of diversity and inclusion provides opportunities for young people to consider the range and extent of diversity in societies locally and globally and to identify the challenges and opportunities which diversity and inclusion present.

- Investigating diversity in a local and global citizenship context is about encouraging young people to see the breadth of diversity in their own community and the challenges and opportunities that this may bring. Such an investigation would involve appropriate exploration of issues like gender, sexuality, ethnicity, religion, political beliefs etc., which would be in local, national and global contexts.

Equality and social justice:

- Investigation of the concepts of equality and justice provides opportunities for young people to understand that inequality and injustice exist; that they have an impact on individuals, groups and society; and that individuals, governments and society have responsibilities to promote equality and justice.

- Investigating Equality and Social Justice in a local and global citizenship context is about allowing young people opportunities to examine how inequalities can arise in society and how some people can experience inequality or discrimination on the basis of their group identity e.g. section 75 groups- racial group, disability, religious beliefs, gender etc. Furthermore investigating how some people are excluded from playing a full part in society as a result of their material circumstances will help young people engage with a range of social justice issues like homelessness, poverty and refugees.

Democracy and active participation:

- Investigation of the concepts of democracy and active participation provides opportunities for young people to understand how to participate in, and to influence democratic processes and to be aware of some key democratic institutions and their role in promoting inclusion, justice and democracy.

- It is very important to highlight that in addressing this theme, teachers should move from teaching about democracy to living out democracy; this implies that once young people have learned about the characteristics of democracy and the institutions of democracy, they should be engaged in processes that lets them live out these principles.

- The investigation of democratic processes help young people to see how they can narrow the gap between the world as it is and their ideal world. It is important that young people have a sense of the possibility of change and an understanding of their potential role in bringing about change using democratic means.

Human rights and social responsibility: 
- Human Rights and Social Responsibility is the core theme of local and global citizenship. Young people should be provided with opportunities to understand that a globally accepted values-base exists, within the various human rights international charters, which outline the rights and responsibilities of individuals and groups in democratic societies.

- Rights and values will clash in any society. Young people should consider how to handle these conflicts through democratic processes. It then becomes important to consider how, in a diverse society which aspires to be just and equitable, individuals and groups can influence the decision making process.

CCEA guidance material goes on to highlight that the learning associated with LGC should take account of issues of social and political concern, issues related to identity and expressions of cultural identity, relevant human rights principles and aspects of the law, and the role of the media. Its goal is to enable young people to participate positively and effectively in society, to influence democratic processes, and to make informed and responsible choices as citizens. In addition, the guidance suggests that it should help young people understand the role of individuals, society and government in working for a more inclusive, just and democratic society. Progression across the curriculum is illustrated on Figure 1.

For pupils in the last two years of compulsory education (aged 15 to 16 years) it was expected that they should be enabled to:

- respond to the specific challenges and opportunities which diversity and inclusion present in Northern Ireland and the wider world;

- identify and exercise their rights and social responsibilities in relation to local, national and global issues;

- develop their understanding of the role of society and government in safeguarding individual and collectives rights in order to promote equality and to ensure that everyone is treated fairly;

- develop their understanding how to participate in a range of democratic processes;

- develop awareness of key democratic institutions and their role in promoting inclusion, justice and democracy;

- develop awareness of the role of non-governmental organisations

Each of these 'statements of requirement' was further exemplified in greater detail in the curriculum guidance material. Assessment of these requirements can be carried out through self-assessment, portfolios and journals, and assessment for learning methods. In addition, pupils take a GCSE public examination at the end of Key Stage 4 on Learning for Life and Work. After each examination cycle a report on the patterns of responses is issued. The report for January 2015 indicated that a majority of pupils were able to answer almost all of the questions, but only about half were able to fully explain the role of a statutory body (in this case the Police Ombudsman's Office) and there appeared to be some confusion among pupils between laws and rights.

\section{The implementation of citizenship education in Northern Ireland and critical reflections}


Perhaps not surprisingly the new citizenship programme was subject to critical comment for a variety of reasons. A number of commentators pointed to lacunae in its focus: Gallagher (2007) suggested that it over-played sectarian divisions and under-played racism in Northern Ireland. Deiana (2013) highlighted the fact that the GFA had contained '... promises of inclusion and equality ... [but] the new institutional framework and subsequent policy decisions, have retained gendered exclusions and perpetuate gendered stereotypes' (p400). Deiana went on to argue that the GFA had 'institutionalised ethnonationalism as a dominant political discourse' (p409) to the extent that politics came to be dominated by ethnic bloc interests and the issue of gender equality had receded as a political priority, despite the active role of women's groups in community politics and the role of the Women's Coalition in the peace talks. Restoring this focus might lead to a 'more inclusive notion of citizenship' (p410).

Another critical theme focused on various tensions that were identified in the programme. McKeever and O'Rawe (2007) felt that the rights dimension of citizenship needed to be strengthened, precisely because the programme was being introduced in a divided society that was newly emerging from political violence. The tension between particularistic identities and a common identity was also highlighted by Neins and Chastenay (2008) who suggested that the challenge of achieving a more peaceful social climate though citizenship education would require a greater balance between the 'preservation of cultural identity and allegiance to a shared vision' (p535). Niens and Mcllrath (2010) identified a potential tension between the principles of democracy which would be embedded in a programme of citizenship education and the fact that schools themselves were not democratic institutions. The citizenship education programmes differed in each part of the UK and commenting on this Kisby and Sloam (2012) suggested that the relative closeness of the devolved Assemblies made it more likely that locally elected politicians would play an active role in schools in promoting a positive approach to politics, as compared with the greater distance of Westminster MPs from 'the people'. By contrast, Hays (2010) felt that despite the unsteady first few years of the NI Assembly, and the limited positive example of effective politics it provided, locally elected councils should seek to generate superordinate goals which might act as a positive catalyst for citizenship education in schools.

Some of the research highlighted above has commented on the pilot programme for citizenship education in Northern Ireland and on the implementation of the programme as it was rolled out across the school system. A number of further papers have evaluated aspects of citizenship education. Niens and Reilly (2012) focused on the notion of global citizenship as a universalising framework and whether this would help young people in Northern Ireland transcend particularistic identities. They talked with students about the concept and found that they liked it and were able to engage with the issues in an open way. However, Niens and Reilly (2012) also found few connections, or critical reflection, being made between global citizenship and local identities. More worrying, their evidence suggested that Protestant and Catholic schools in Northern Ireland appeared to address the concept of global citizenship in different ways, opening up the possibility that this could generate parallel discourses on the issue.

McMurray and Niens (2012) explored whether the participatory model for teaching citizenship, and more particularly the encouragement to work with NGOs and local communities outside the schools, might help to build 'bridging social capital' and encourage connections between divided 
communities. They collected data using school surveys, focus groups, and interviews with students and educators. They found that schools often had pre-existing links with local community organisations and NGOs and continued to use these as part of their work on citizenship education. However, the existing networks differed between the denominational school sectors and they found little evidence that new networks that cut across the wider societal divide were being established. Their conclusion was that the implementation of participatory citizenship education may therefore be reinforcing existing intra-community connections, or 'bonding social capital', rather than forging new inter-community connections. O'Connor (2012) also explored connections with groups outside schools, this time an educational initiative, the Spirit of Enniskillen, run by young people which provided support for active learning techniques. The paper was primarily an evaluation of the Spirit of Enniskillen initiative, and was positive, but it also concluded that the platform provided by citizenship education provided a strong basis for collaboration between the formal and non-formal education sectors.

Niens et al. (2013) focused on the experiences of teachers and their understanding of citizenship education following participation in a special training programme; they were also interested in the way the teachers engaged with controversial and difficult issues. Their analysis identified a gap in the citizenship curriculum in that it did not provide a focus on the tension between notions of 'Britishness' and 'Irishness', and the relationship between these identities and the contested nature of the Northern Ireland polity. According to Niens et al. (2013) the avoidance of any consideration of this contested 'national' context meant that this issue is 'not only 'trivialised' but represents a conglomeration of the immediate, local environment (school) and a wider, global context (environmental impact that reaches beyond national boundaries)' ( $p 133$ ).

Having identified this lacuna in the curriculum, Niens et al. (2013) went on to explore teachers' engagement with controversial issues. The teachers offered mixed views on the extent to which they dealt directly with difficult issues such as sectarianism: most agreed that this was one of the most challenging aspects of teaching citizenship in Northern Ireland, but most also said they felt confident in doing so. There were some who said that the issue never arose in their classroom, which Niens et al. (2013) suggested may represent 'an underestimation of underlying sectarian attitudes amongst pupils as well as a tendency not to address such topics unless it is seen as a behavioural issue disrupting relationships within the school' (p134). There were others who avoided the issue through a more general focus on poverty or homelessness. While most saw sectarianism and racism to be linked, most also felt the latter to be an easier topic to address within classrooms. The overall conclusion of the paper is that the constraints identified could limit the potential for citizenship education in addressing social division and conflict, and providing the basis for engaging pupils in the pursuit of positive peace.

A more focused critique was provided by McEvoy et al. (2006) who dismissed most of the education work that had been done over a thirty year period in schools to promote reconciliation and suggested it had been side-lined as part of the peace process. They critiqued the concept of reconciliation as it was articulated through what they describe as the 'community relations' paradigm: this paradigm, it is claimed, was promoted by the British government and liberal sections of unionism; was primarily concerned with enlisting Catholics in an assimilationist agenda; sought to undercut political support for militant Irish Republicanism; attempted to side-line community 
activists in favour of elected politicians; avoided a focus on equality and rights; and claimed to address social division while remaining uncritical of the legitimacy of the state (McEvoy et al., 2006: 85). Furthermore they argued that theoretical and policy frameworks were developed in order to cast the conflict as an internal one between two communities with intolerance and individual prejudice as the root issues, as opposed to inequality. The paper goes on to dismiss integrated education, contact initiatives and previous curriculum initiatives as failed elements of the 'community relations paradigm' and suggests that citizenship education, with human rights at its core, could form the basis of an alternative paradigm, a theme further developed by McCully and Emerson (2014).

By contrast McEvoy et al. (2006) laud the role of 'ex-combatants' ${ }^{1}$ who they suggest did most of the 'heavy lifting' during the peace process and were more responsible for promoting positive change and conflict transformation than any of those operating within the 'community relations paradigm'. 'They have the credibility to engage in such real reconciliation work in the working class areas in which it is most needed' (McEvoy et al., 2006: 99) because of a number of key characteristics: their work is not based on false representations of friendship, but rather on an acknowledgement of the need to respects the rights of the other; it is not about the creation of a diluted and neutral middle ground, but of the engagement between those confident in their own identities; it is focused on solving real problems, such as parading, rather than 'ill-focused explorations of prejudice reduction' (McEvoy et al., 2006: 99); and it is based on the need to have strong mechanisms for state accountability.

The power of this critique lies in its clarity, but this is only possible because it essentialises what is, in reality, a much more complex mix of initiatives, people, motives and achievements. It ignores work within the 'community relations paradigm' which provided empirical evidence on inequality in labour market and educational outcomes, and which led to significant policy change; it attributes a singularity of motive to a vast array of different groups, over many years; or alternatively implies that many were hapless dupes of a political project which they either ignored, misunderstood, or complied. In seeming to require any practical action to engage with the question of the legitimacy of the Northern Ireland polity, the analysis also seemed to ignore the fact that prejudice and discrimination did act as very real problems in day-to-day life: just because some people sought to challenge prejudice did not mean that they assumed this was the only problem in Northern Ireland, and not all the academic frameworks used to understand the dynamics of prejudice cast it as an individualistic or irrational phenomenon, devoid of political implications. It is also the case that the consociational arrangements in the political institutions arising from the GFA have arguably done more to promote the notion of 'two communities' as the key dynamic of relationships in Northern Ireland (Taylor, 2006; McGlynn et al., 2014). Inter alia, we know that issues such as parading, poverty and economic inactivity, or educational underachievement are far from being solved, and most proposals that have emerged to address the legacy of the past have failed to achieve political consensus.

\footnotetext{
${ }^{1}$ The nomenclature here is complex: a wide variety of terms are used - including 'ex-combatants', 'ex-political prisoners', 'terrorists', or 'paramilitaries' - all of which potentially carry pejorative overtones.
} 
Despite the weaknesses in the McEvoy et al., (2006) analysis, two useful elements did emerge from it: first, the focus on rights as a core element of citizenship education could have provided a set of universalist principles to cast light on contentious issues, or at least provided young people with a sense that there were principles available to aid judgement that did not 'belong to' any particular community, although McEvoy (2007) expressed concern that the citizenship programme had been weakened in this respect in its final stages of development; second, it provided the impetus for a challenging education initiative in which young people were given access to the views of ex political prisoners in order to broaden their understanding of the reasons behind the violent conflict in Northern Ireland. Emerson (2012) provides an outline of the genesis and implementation of this project, Prison to Peace, which was based on the principle that:

'... the narratives of those who have been involved directly as both combatants in conflict and latterly as agents of change in their communities provide unique opportunities for young people to reflect on these issues.' (Emerson, 2012: 279).

The project involved former prisoners from Protestant/Loyalist and Republican paramilitaries engaging with young people to help them better understand the complexities of conflict and the intricacies of transition. Emerson (2012) suggested that the citizenship curriculum makes it too easy to avoid difficult and controversial areas, something which is much harder to avoid in the Prison to Peace initiative. She went on to suggest that without the opportunity to engage with these difficult issues young people may grow up to integrate their partial understanding with partial, community accounts and, in this way, perpetuate myths about the historical antecedents of the conflict. More controversially, Emerson (2012) suggests that the initiative will promote the:

'... capacity for 'political generosity' [which] is in essence the ability to legitimise the cultural and political identity of those with opposing views, primarily on the basis of their right to hold them'. (Emerson, 2012: 290)

Just how far this sense of 'political generosity' is supposed to extend is unclear, and Edwards and McGrattan (2012) cast this initiative as one of a number which have the effect of 'valorising terroristic narratives over the very real effect of violence on victims ...' (p.365). However, the evaluation of the initiative reported by Emerson et al. (2014:4) makes clear that its aims were to:

- prevent young people from becoming involved in violence through presenting the realities of the conflict and the prison experience from the point of view of those who had been directly involved in the conflict;

- demonstrate to young people alternative ways of dealing with conflict which do not necessarily require individuals to give up their political aspirations or cultural identity;

- present young people with alternative perspectives on the conflict through a comprehensive and complex picture of the political ex-prisoner experience;

- and provide young people with an opportunity to engage directly with those who were involved in the conflict in panel discussions with ex-prisoners

Clearly, therefore, the initiative did not aim to encourage sympathy, or even empathy, for decisions to take up violence, but rather the ex-prisoners sought to encourage young people to follow political 
paths that would not take them down the road they themselves had followed. The evaluation found that young people who had participated in the initiative knew more about the conflict, processes of transitional and conflict transformation; demonstrated more support for using non-violent means to deal with conflict; and demonstrated less blatant and subtle prejudice, in comparison with young people who had not. In addition, the initiative seemed to have increased young people's likelihood of being engaged politically, as measured by such indicators as talking to others more about politics, showing more interest in participating in school related activities, or seeking more information related to politics.

An apparent gap in the evidence discussed above lies in the notion of justice. In the curriculum specification the only reference to justice is in relation to "key democratic institutions and their role in promoting inclusion, justice and democracy' (CCEA, 2012: 8). In part the gap in the literature may arise because the concept of justice can be seen to operate in at least three different spheres: 'justice' as a legal concept based on the identification of responsibility and allocation of punishment; 'social justice' with a focus on equality and inclusion; or 'transitional justice' with a focus on the processes which will aide a move from conflict to stability. Within the curriculum the link between justice and equality may serve to emphasise the 'social justice' dimension of the concept, which can also be seen in the focus on such issues as poverty, homelessness and refugees. Of the papers considered above only Emerson (2012) engages with the concept of justice, but this is mainly to steer the notion away from a legal focus on retribution towards an approach which emphasises transitional justice. Emerson (2012) suggests that:

'... while historically transitional justice has viewed itself as primarily a 'victim centred discourse' increasingly the framework has been broadened to encompass an understanding that the fate of ex-combatants and ex-prisoners is at least as important in securing the durability of long-term peace ...' (Emerson, 2012: 278).

This is so, she suggests, because the cooperation of 'ex-combatants' is necessary in order to pursue some transitional goals, such as disarmament, locating bodies of the disappeared, truth recovery and the reintegration of 'ex-combatants' into society.

The challenge is that a focus on the 'social justice' dimension may encourage avoidance of some of the difficult issues facing a society emerging from violent conflict, while a focus on 'transitional justice' may lead to the de facto setting-aside of the 'justice' dimension of identifying responsibility (whatever decisions may be considered around the administration of punishment or its mitigation through a process of forgiveness). An emphasis on the 'legal' aspect of justice may be a particular problem in Northern Ireland because, of the approximately 3,700 people who died as a consequence of the political violence, it is possible that those responsible for the deaths may have been held to account in less than half of all cases. Even identifying the number of 'unsolved murders' is challenging: as part of the peace process the police established an Historical Enquiries Unit to investigate unsolved murders. When the HEU was launched in 2005 it was suggested that 1,800 cases fell within its remit, but this seemed to have excluded all cases where someone had been killed by a member of the security forces. Following lobbying by NGOs and others, the number to be investigated increased to 3,268 using the criterion that they would look at cases that were unresolved from the families' perspective. The Unit was significantly downsized in 2014 (for more 
detailed accounts on these issues see Lundy, 2009 and Amnesty International, 2013). The main point from this is that when 'truth' and 'responsibility' appear to be so limited, even thread-bare, then articulating a robust sense of 'justice' may be very difficult, at a societal level, never mind in the school curriculum. For this reason the 'justice' dimension of the citizenship curriculum in Northern Ireland may be under-developed and the various tensions explored above left unresolved.

Returning to the more formal evaluation of the implementation of the curriculum, there is limited inspection evidence on the impact of citizenship education in Northern Ireland, but the most recent report from the Education and Training Inspectorate on the implementation of the revised Northern Ireland Curriculum overall suggests that between 2012 and 2014, 'one-quarter of the PDMU [personal development and mutual understanding] lessons in primary schools and one-third of citizenship and PD [personal development] lessons in post-primary schools were not effective' (ETI, 2015: 10).

Using evidence of direct engagement in electoral politics is probably not the most appropriate criterion on which to judge the impact of citizenship education, although it is not an entirely irrelevant criterion. Given that caveat, evidence from the Northern Ireland Life and Times Survey (http://www.ark.ac.uk/nilt/ - last accessed January 1, 2016) suggests that young people are least likely to vote or hold much interest in party politics, in comparison with older cohorts. In the 2002 survey only 39 per cent of 18-24 year olds said they had voted in the 2001 general election, in comparison with 60 per cent or more for all other age groups. In the 2010 survey only 23 per cent of 18-24 year olds said they had voted; 46 per cent of 25-34 year olds said they had voted, as did more than half of all the other age groups. In the 1998 survey respondents were asked how much interest they had generally in what is going on in politics: less than a quarter of 18-24 year olds said they were interested a great deal or quite a lot, in comparison with between a third and two-fifths of all other age categories. In the 1009 survey respondents were asked how interested they were personally in politics: only 19 per cent of 18-24 year olds said they were fairly or very interested, in comparison with between a quarter and two fifths of all other age groups. Young people in Northern Ireland may engage in politics through participation in campaigns and NGOs, but there is little evidence that the period in which citizenship education has been a required part of the curriculum of schools has been marked by a growing interest amongst the young in formal politics.

\section{Conclusion}

We noted above that Arlow (2001) identified the citizenship education programme in Northern Ireland as a potential turning point in the response of the education system to the conflict. The delineation of the curriculum required careful navigation between a range of competing political and conceptual tensions, and inevitably there were commentators who highlighted weaknesses and gaps in the programme as it eventually emerged. Citizenship education in more politically stable countries often focuses on the symbols and rituals of citizenship, such as the national flag, national anthem, political institutions, office of the president or monarch, or the wider statutory framework through which entitlements are delivered or responsibilities managed. Since many of these features are contested in Northern Ireland, an important feature of the citizenship curriculum was the attempt to focus on the processes of citizenship in order to provide young people with the concepts, language and ideas that might allow them to participate in constructing what it meant to be a citizen in 
Northern Ireland in the $21^{\text {st }}$ century: in other words, its focus was not in teaching them about what it was, but in helping them to be part of the process of making what it might be. Whether this lofty ideal has been realised in practice might seem in doubt: despite an extensive and well-resourced training programme to build capacity in the schools to deliver the curriculum there was limited follow-up work to build networks among citizenship education teachers and it is unclear just what status the subject has within schools. Certainly the evidence from the Education and Training Inspectorate would suggest that there are significant problems, while the evidence on engagement and interest of young people in formal politics is not encouraging. Nevertheless, the curriculum which emerged was imaginative and creative, and it spawned some equally imaginative, if controversial, initiatives. But it is possible that a divided society will never escape the shackles of the past unless it is prepared to engage with the difficult issues which contributed to political violence, and if we cannot address these issues seriously within education, then it is hard to know where they can be addressed.

As a final note, three ideas may be worthy of further work and consideration in trying to find ways of improving the delivery of citizenship education in Northern Ireland:

- First, a number of commentators have pointed to the challenge of denominational schools in delivering effective citizenship education in Northern Ireland. The development of the 'shared education' approach since 2006, in which schools work in collaborative networks, and students and teachers move between schools provides a different context in the relationships between schools in local areas, and its impact on the delivery of citizenship education may be worthy of deeper consideration (Duffy and Gallagher, 2014).

- Second, if we follow the lead provided by the Prison to Peace project, which created opportunities for young people to engage with ex-political prisoners with very different backgrounds and political outlooks, perhaps there should be more effort put into engaging politicians with young people in schools, preferably in a similar manner, as part of an explicit process of trying to build trust and participation in formal political activity.

- Third, most of the challenges of delivering effective citizenship education in Northern Ireland derive from the fact that it is a divided society that is struggling to emerge from an extended period of political violence. It is not the only example of a society facing this type of challenge in these type of circumstances, so more comparative engagement on the lessons learned in different jurisdictions might be valuable.

\section{$\underline{\text { References }}$}

Akenson, D.H. (1970) The Irish Education Experiment: the national system of education in the nineteenth century, London: Routeldge and Kegan Paul.

Akenson, D.H. (1973) Education and emnity: the control of schooling in Northern Ireland 1920-1950, London: David and Charles.

Amnesty International (2013) Northern Ireland: time to deal with the past. London: Amnesty International.

Arlow, M. (2001) The challenges of social inclusion in Northern Ireland: citizenship and life skills. in S. Tawil (Ed.) Curriculum Change and Social Inclusion: Perspectives from the Baltic and 
Scandinavian Countries, Final Report of the Seminar Held in Vilnius, Lithuania, Pp 38-43. Open Society Fund-Lithunania/International Bureau of Education

Arlow, M. (2004) Citizenship education in a divided society: the case of Northern Ireland. In S. Tawhil and A. Harley (Eds.) Education, Conflict and Social Cohesion (Pp255-314), Geneva:

International Bureau of Education

Ben-Porath, S (2011). Wartime citizenship: an argument for shared fate. Ethnicities, 11(3), 313-325

Burns (2001) Education for the 21st Century: report of the post primary review group (Burns Report), Bangor: Department of Education

CCEA (2012) CCEA GCSE Specification in Learning for Life and Work. Belfast: Council for the Curriculum, Examinations and Assessment

Daly, M (2001) Irish nationality and citizenship since 1922, Irish Historical Studies, 127, 377-407

Darby, J. (1997) Scorpions in a Bottle: conflicting cultures in Northern Ireland, London: Minority Rights Group

Deiana, M.-A. (2013) Women's Citizenship in Northern Ireland after the 1998 Agreement, Irish Political Studies, 28:3, 399-412

Department of Education (1998) Towards a culture of tolerance: integrating education. Bangor: Department of Education

Department of Education (1999) Towards a culture of tolerance: education for diversity. Bangor: Department of Education

Duffy, G. and Gallagher, T. (2014) Sustaining school partnerships: the context of cross-sectoral collaboration between schools in a separate education system in Northern Ireland. Review of Education, 2(2), 189-210.

Durkheim, E (author) and Lukes, S (Ed) The division of labour in society. London: Palgrave Macmillan

Edwards, A. and McGrattan, C. (2011): Terroristic Narratives: On the (Re) Invention of Peace in Northern Ireland, Terrorism and Political Violence, 23:3, 357-376

Emerson, L. (2012) Conflict, transition and education for 'political generosity': learning from the experience of ex-combatants in Northern Ireland, Journal of Peace Education, 9:3, 277-295

Emerson, L., Orr, K. and Connolly, P (2014) Education of the effectiveness of the 'prison to peace: learning from the experience of political ex-prisoners' educational programme. Belfast: OFMDFM

ETI (2015) An evaluation of the impact of the CRED policy in schools and youth organisations, Belfast: Education and Training Inspectorate for Northern Ireland

Evaluation Findings. Belfast: CCEA.

Gallagher, E (2007) Racism and citizenship education in Northern Ireland, Irish Educational Studies, 26(3), 253-269

Gallagher, $T$ (2005) Balancing difference and the common good: lessons from a post-conflict society, Compare: A Journal of Comparative and International Education, 35(4), 429-442

Gallagher, T (2011) Response: when war and peace collide. Ethnicities, 11(3), 331-335

Gallagher, T. (2004) Education in Divided Societies, London: Palgrave/MacMillan.

Gallagher, AM, Cormack, RJ and Osborne, RD (1994). Religion, equity and education in Northern Ireland. British Educational Research Journal, 20(5), 507-518.

Hays, R.A. (2010) The evolution of citizenship in a divided urban community: local citizen engagement in Belfast, Northern Ireland. Urban Affairs Review, 45(3), 336-376

Heskin, K. (1980) Northern Ireland: A Psychological Analysis. Dublin: Gill and Macmillan 
Horgan, $\mathrm{G}$ and Rodgers, P (2000) Young people's participation in a new Northern Ireland Society, Youth and Society, 32(1), 107-137

Kisby, B. and Sloam, J. (2012) Parliamentary Affairs, 65, 68-89

Lister, $R$ (1998) Citizen in action: citizenship and community development in a Northern Ireland context. Community Development Journal, 33(3), 226-235

Lundy, P (2009) Journal of Law and Social Challenges, 11, 2009, 109-156

McCully, A. and Emerson, L. (2014) Teaching controversial issues in Northern Ireland. In: Crosscultural Case-studies in Controversial Issues: Pathways and Challenges in Democratic Citizenship Education. T. Misco, Thomas and J. de Groof (Eds), Legal Wolf Publishers, Tilberg

McEvoy, L (2007) Beneath the rhetoric: policy approximation and citizenship education in Northern Ireland. Education, Citizenship and Social Justice, 2(2), 135-157

McEvoy, L., McEvoy, K. and McConnachie, K (2006) Journal of International Affairs, 60(1), 81-106

McGlynn, C., Tonge, J. and McAuley, J. (2014) The party politics of post-devolution identity in Northern Ireland, The British Journal of Politics and International Relations, 16, 273-290

McKeever, G and O'Rawe, M (2007) Political ex-prisoners and policing in transitional societies testing the boundaries of new conceptions of citizenship and security. Internaitonal Journal of Law in Context, 3, 105-125

McMurray, A. and Niens, U (2012) Building bridging social capital in a divided society: The role of participatory citizenship education, Education, Citizenship and Social Justice, 7(2), 207-221

Neins, U. and Chastenay, M-H. (2008) Educating for peace? Citizenship education in Quebec and Northern Ireland, Comparative Education Review, 52(4), 519-540

Niens, U. and Mcllrath, L. (2010) Understandings of citizenship education in Northern VIreland and the Republic of Ireland: public discourses among stakeholders in the public and private sectors, Education, Citizenship and Social Justice, 5(1) 73-87

Niens, U. and Mcllrath, L. (2010) Understandings of citizenship education in Northern VIreland and the Republic of Ireland: public discourses among stakeholders in the public and private sectors, Education, Citizenship and Social Justice, 5(1) 73-87

Niens, U. and Reilly, J. (2012) Education for global citizenship in a divided society? Young people's views and experiences, Comparative Education, 48:1, 103-118

Niens, U., O'Connor, U. and Smith, A. (2013) Citizenship education in divided societies: teachers' perspectives in Northern Ireland, Citizenship Studies, 17(1), 128-141

O'Connor, U. (2012) Schools together: enhancing the citizenship curriculum through a non-formal education programme, Journal of Peace Education, 9:1, 31-48

Richardson, N and Gallagher, T (2010) Education for diversity and mutual understanding, Germany: Peter Lang

Rose, R. (1976) On the Priorities of Citizenship in the Deep South and Northern Ireland, The Journal of Politics, 38(2), 247-291

Smith, A (2003) Citizenship Education in Northern Ireland: Beyond national identity? Cambridge Journal of Education, 33(1), 15-32

Taylor. R. (2006) The Belfast Agreement and the politics of consociationalism: a critique. The Political Quarterly, 77(2), 217-226

Watling, R. and Arlow, M. (2002) Wishful Thinking: Lessons from the Internal and External Evaluations of an Innovatory Education Project in Northern Ireland, Evaluation \& Research in Education, 16:3, 166-181 
Whitty, G., Rowe, G. and Aggleton, P (1994) Subjects and themes in the secondary-school curriculum, Research Papers in Education, 9(2), 159-181

Wylie, K. (2004) Citizenship, identity and social inclusion: lessons from Northern Ireland. European Journal of Education, 39(2), 237-248 